\title{
Front Matter: Volume 7094
}

, "Front Matter: Volume 7094," Proc. SPIE 7094, Unconventional Imaging IV, 709401 (3 September 2008); doi: 10.1117/12.806333

SPIE Event: Optical Engineering + Applications, 2008, San Diego, California, United SPIE. States 


\section{PROCEEDINGS OF SPIE}

\section{Unconventional Imaging IV}

Jean J. Dolne

Thomas J. Karr

Victor L. Gamiz

Editors

11 August 2008

San Diego, California, USA

Sponsored and Published by

SPIE

Volume 7094

Proceedings of SPIE, 0277-786X, v. 7094 
The papers included in this volume were part of the technical conference cited on the cover and title page. Papers were selected and subject to review by the editors and conference program committee. Some conference presentations may not be available for publication. The papers published in these proceedings reflect the work and thoughts of the authors and are published herein as submitted. The publisher is not responsible for the validity of the information or for any outcomes resulting from reliance thereon.

Please use the following format to cite material from this book:

Author(s), "Title of Paper," in Unconventional Imaging IV, edited by Jean J. Dolne, Thomas J. Karr, Victor L. Gamiz, Proceedings of SPIE Vol. 7094 (SPIE, Bellingham, WA, 2008) Article CID Number.

ISSN 0277-786X

ISBN 9780819473141

Published by

SPIE

P.O. Box 10, Bellingham, Washington 98227-0010 USA

Telephone +1 3606763290 (Pacific Time) · Fax +1 3606471445

SPIE.org

Copyright (C 2008, Society of Photo-Optical Instrumentation Engineers

Copying of material in this book for internal or personal use, or for the internal or personal use of specific clients, beyond the fair use provisions granted by the U.S. Copyright Law is authorized by SPIE subject to payment of copying fees. The Transactional Reporting Service base fee for this volume is $\$ 18.00$ per article (or portion thereof), which should be paid directly to the Copyright Clearance Center (CCC), 222 Rosewood Drive, Danvers, MA 01923. Payment may also be made electronically through CCC Online at copyright.com. Other copying for republication, resale, advertising or promotion, or any form of systematic or multiple reproduction of any material in this book is prohibited except with permission in writing from the publisher. The CCC fee code is $0277-786 \mathrm{X} / 08 / \$ 18.00$.

Printed in the United States of America.

Publication of record for individual papers is online in the SPIE Digital Library.

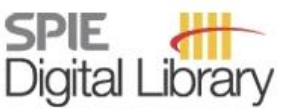

SPIEDigitallibrary.org

Paper Numbering: Proceedings of SPIE follow an e-First publication model, with papers published first online and then in print and on CD-ROM. Papers are published as they are submitted and meet publication criteria. A unique, consistent, permanent citation identifier (CID) number is assigned to each article at the time of the first publication. Utilization of CIDs allows articles to be fully citable as soon they are published online, and connects the same identifier to all online, print, and electronic versions of the publication. SPIE uses a six-digit CID article numbering system in which:

- The first four digits correspond to the SPIE volume number.

- The last two digits indicate publication order within the volume using a Base 36 numbering system employing both numerals and letters. These two-number sets start with 00, 01, 02, 03, 04, 05, $06,07,08,09,0 A, 0 B \ldots .0 Z$, followed by $10-1 Z, 20-2 Z$, etc.

The CID number appears on each page of the manuscript. The complete citation is used on the first page, and an abbreviated version on subsequent pages. Numbers in the index correspond to the last two digits of the six-digit CID number. 


\section{Contents}

$\checkmark \quad$ Conference Committee

\section{SESSION 1 IMAGE ENHANCEMENT AND SUPER-RESOLUTION}

709402 OTF compensation in structured illumination superresolution images (Invited Paper) [7094-01]

S. A. Shroff, J. R. Fienup, D. R. Williams, Univ. of Rochester (United States)

709403 Simulation of a passive grating-heterodyne super-resolution concept [7094-02]

D. W. Tyler, Lockheed Martin Space Systems Co. (United States) and College of Optical Sciences, The Univ. of Arizona (United States); E. B. Barrett, Lockheed Martin Space Systems Co. (United States)

709404 Phase error correction for multiple planes using sharpness metrics [7094-03]

A. E. Tippie, J. R. Fienup, Univ. of Rochester (United States)

709405 Pixon sub-diffraction space imaging [7094-04]

R. C. Puetter, Pixonlmaging LLC (United States); R. G. Hier, DigiVision, Inc. (United States)

709406 Image fusion and sampling artifacts [7094-05]

G. C. Holst, JCD Publishing Co. (United States)

\section{SESSION 2 SENSOR CHARACTERIZATION}

709407 PSF uncertainty and image estimation errors [7094-06]

S. Prasad, Univ. of New Mexico (United States)

709408 Analysis and verification of resolution limits of a hyperspectral imager using computed tomography [7094-07]

S. Mantravadi, S. Cain, Air Force Institute of Technology (United States)

709409 Remote ultra-low light imaging (RULLI) for space situational awareness (SSA): modeling and simulation results for passive and active SSA [7094-08]

M. C. Roggemann, Michigan Technological Univ. (United States); K. Hamada, Pacific Defense Solutions (United States); S. R. Gudimetla, K. LuU, Air Force Research Lab. (United States); L. W. Bradford, D. C. Thompson, R. Shirey, Los Alamos National Lab. (United States)

7094 OA Limitations on sensors exploiting airglow for no light imaging [7094-09]

R. G. Madonna, Northrop Grumman Electronic Systems (United States)

7094 OB Real-time hardware realization of a deblurring anisoplanaticism corrector (DAC) for improvement of long-range video imagery [7094-10]

R. G. Hier, DigiVision, Inc. (United States); R. C. Puetter, PixonImaging LLC (United States) 
SESSION 3 IMAGE SYNTHESIS AND ACTIVE IMAGING

7094 OE Active multi/hyperspectral imaging and sensing with ultra-short pulse continuums [7094-13] K. A. Blanks, The Aerospace Corp. (United States)

7094 OF Optical antenna of telescope for synthetic aperture ladar [7094-14]

L. Liu, Shanghai Institute of Optics and Fine Mechanics (China)

\section{SESSION 4 ACTIVE IMAGING}

7094 OG Laboratory demonstration of a multiple beam Fourier telescopy imaging system [7094-16] E. L. Cuellar, J. Cooper, J. Mathis, P. Fairchild, Trex Enterprises Corp. (United States)

Author Index 


\title{
Conference Committee
}

\author{
Conference Chairs \\ Jean J. Dolne, The Boeing Company (United States) \\ Thomas J. Karr, Northrop Grumman Corporation (United States) \\ Victor L. Gamiz, Air Force Research Laboratory (United States) \\ Program Committee \\ Paul W. Fairchild, Trex Enterprises Corporation (United States) \\ James R. Fienup, University of Rochester (United States) \\ Richard M. Heinrichs, MIT Lincoln Laboratory (United States) \\ Charles L. Matson, Air Force Research Laboratory (United States) \\ Paul F. McManamon, Air Force Research Laboratory (United States) \\ Timothy J. Schulz, Michigan Technological University (United States) \\ Robert K. Tyson, The University of North Carolina at Charlotte \\ (United States) \\ Laura J. Ulibarri, Air Force Research Laboratory (United States) \\ David G. Voelz, New Mexico State University (United States)
}

Session Chairs

1 Image Enhancement and Super-Resolution

Victor L. Gamiz, Air Force Research Laboratory (United States)

2 Sensor Characterization

Jean J. Dolne, The Boeing Company (United States)

3 Image Synthesis and Active Imaging

Thomas J. Karr, Northrop Grumman Corporation (United States)

$4 \quad$ Active Imaging

James R. Fienup, University of Rochester (United States) 
Downloaded From: https://www.spiedigitallibrary.org/conference-proceedings-of-spie on 26 Apr 2023

Terms of Use: https://www.spiedigitallibrary.org/terms-of-use 